Sustainable Well-Being in Israel

Report of the Expert Committee of The Israel Academy of Sciences and Humanities

\title{
Israel - The Human Capital Perspective
}

Dov Chernichovsky • Ben-Gurion University of the Negev

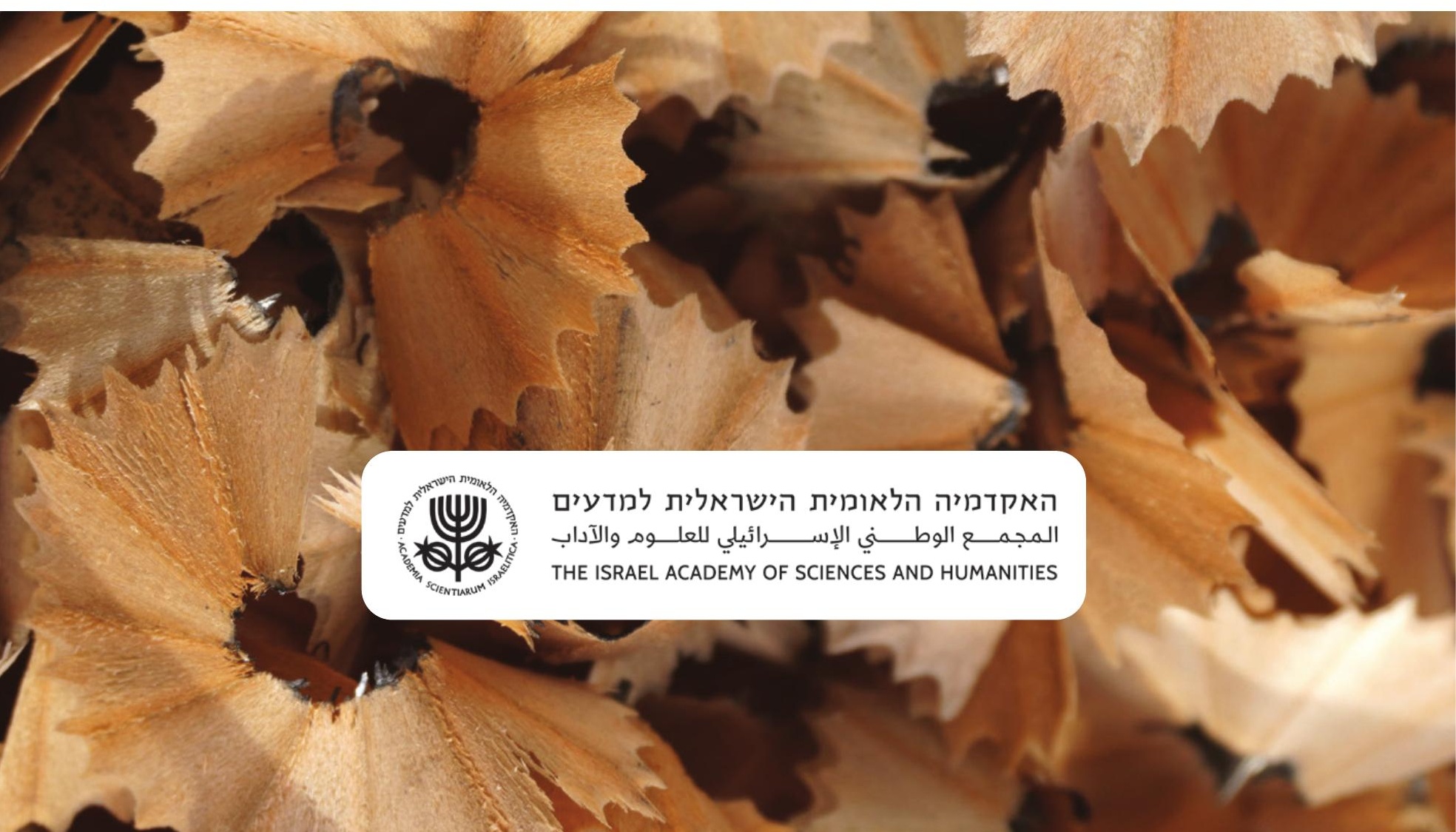


This review was commissioned as part of the work of the Expert Committee of The Israel Academy of Sciences and Humanities on Sustainable Well-Being in Israel.

The full report of the committee is available on the Academy's website:

\section{https://doi.org/10.52873/Policy.2021.Wellbeing-en}

(c) The Israel Academy of Sciences and Humanities, 2021

This document is publicly available and may be quoted in its original language. Please use the following credit line when citing or quoting this document:

Dov Chernichovsky (2021). "Israel - The Human

Capital Perspective," Sustainable Well-Being in Israel: Report of the Expert Committee of The Israel Academy of Sciences and Humanities. Jerusalem: The Israel Academy of Sciences and Humanities.

\section{https://doi.org/10.52873/Policy.2021.Wellbeing.04-en}

Project Editor: Yarden Niv

Editing: Deborah Greniman

Design: Studio Noam Tamari

Photography: Shutterstock

The Israel Academy of Sciences and Humanities

Albert Einstein Square, P.O.B 4040, 9104001, Jerusalem

Telephone: +972-25676222

Email: info@academy.ac.il $\underline{w w w . a c a d e m y . a c . i l}$ 


\section{Contents}

1 Introduction 4

A. The Humans

$\begin{array}{ll}\text { B. The Human Capital } & 7\end{array}$

2 Human Capital in Israel 16

A. Demography 16

B. Education and Training - Knowledge and Skill 22

C. Migration, Knowledge, and Skill 24

$\begin{array}{ll}\text { D. Health, Welfare, and Productivity } & 25\end{array}$

3 Conclusion and Policy Recommendations 29

$\begin{array}{ll}\text { A. Population policy } & 29\end{array}$

B. Schooling and training $\quad 30$

$\begin{array}{ll}\text { C. Health } & 32\end{array}$

4 References 33

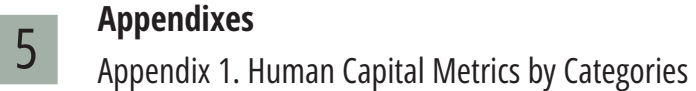




\section{Introduction ${ }^{*}$}

Human capital (HC) is about people - as individuals and as communities - and their welfare-enhancing qualities. For the individual, their human capital is not only an element of well-being, like good health and self-esteem, but also a means to facilitate their welfare, at least in the long term, through longevity as well as market and non-market productivity. For the community - group, organization, or nation - the benefits of $\mathrm{HC}$ to individuals can further be enhanced through social interdependencies, positive externalities, and optimal allocation of $\mathrm{HC}$ in the group, thus making $\mathrm{HC}$ a public good. Investment of a share of the benefits of $\mathrm{HC}$ in its formation makes for social and economic long-term sustainability of the community.

The term "human capital" semantically combines the words "human" and "capital." From an economic point of view, "capital" refers to the physical factors of production, including land, used along with labor-enhanced HC to create goods or services. These factors are not themselves significantly consumed or depreciated in the short-term production process (Boldizzoni, 2008). That is, skilled humans oversee production (and consumption) processes that yield social and economic value for them. From this perspective, human capital essentially refers to people's ability - as individuals and as a collective to identify and use the (physical) resources available to them for their current and future, even intergenerational, well-being. Both the formation and the use of $\mathrm{HC}$ are strongly associated with the demography of the community, mainly with regard to population growth and age distribution, because these determine the community's potential and ability to form and optimally use its $\mathrm{HC}$, subject to the constraint of market failures and imperfections.

\footnotetext{
* Mayuri Mukherjee provided the author with valuable research assistance. The editors are grateful to Dr. Gary Ginsberg for his assistance in preparing the final draft of this report.
} 
The objective of this paper is to indicate (1) challenges relating to the formation and deployment of $\mathrm{HC}$ in Israel, and (2) potential ways to meet these challenges. The first, theoretical part introduces concepts, models, approaches, and metrics. It starts with pertinent aspects of demography that relate to a nation's optimal use of its individuals' human capital and continues with a discussion of critical dimensions of human capital - knowledge and skill, location of economic activity, and health.

The second part of the paper applies these theoretical elements to Israel as a welfare state that encourages and welcomes every Jew to settle in Israel, has an implicit pro-fertility policy, provides close to universal education, and offers universal health coverage. Thus, individual decisions of Israelis about their $\mathrm{HC}$ are highly intertwined with state policy, which can greatly influence those decisions.

\section{A}

\section{The Humans}

\section{- Population Growth}

Population growth is a result of natural growth, driven by relative fertility, mortality, and net migration. Under the influence of Thomas Malthus's 1798 "Essay on the Principle of Population" (Malthus, 1986), population growth was considered to have negative effects on per capita output and income, since, given the Earth's limited resources, it was believed that population growth, driven by "excess" fertility rates and falling mortality, would outpace productivity (especially in relation to the food supply). Julian Simon (1981) countered the prevailing view of population growth as an economic liability; following Marx to an extent, he argued that productivity growth (that is, HC and its benefits) outweighed the potential negative consequences of population growth. The economic development of Japan has been viewed as a case in point. This debate has remained open in the context of questions about the Earth's 
carrying capacity, although lately population growth has been attenuating (Georgescu-Roegen, 1971).

Simon's view has prevailed for now, at least on the national level, ex post facto. Most developed and even transitional economies today, including China, which took harsh measures to control fertility, are experiencing negative population growth rates that, combined with increased longevity and, consequently, growing elderly populations, pose unprecedented economic and societal challenges.

Two issues come into play here: the dependency ratio and migration.

\section{- The Dependency Ratio}

The dependency ratio is the ratio of people who are working to those who are not working in paid employment, mainly because of their age, or because they themselves are engaged in caring for dependents. It relates to the short and long-term capacity, considering demographic and productivity changes, of the working population to sustain the non-working adult and elderly population and the young, while also investing in the latter's HC. Even considering potential productivity growth per worker, a decline in the share of the working population (i.e., an increase in the dependency ratio) may render it insufficient to support - in part by financing public investment - the population depending on it.

Demographic dividend is a relatively recent concept that relates to the dependency ratio. It concerns "a boost in economic productivity that occurs when there are growing numbers of people in the workforce relative to the number of dependents" (UNFPA, 2020; Bloom, Canning, \& Sevilla, 2003). It is assumed that "a country with increasing numbers of young people entering the labor force and declining fertility has the potential to reap a 'demographic dividend"' (UNFPA, 2020).

\section{- Migration}

Migration can shape and regulate the nature and distribution of a country's stock of $\mathrm{HC}$ by influencing the size and quality of the working population. $\mathrm{A}$ 
pro-HC “free rider" immigration policy can augment a nation's HC, with minimal investment, at the expense of the country of origin, especially when training is publicly subsidized there. Canada has become a model in this regard. In 2018, $58 \%$ of new permanent residents were admitted via the "economic stream," which allows federal and provincial authorities to admit highly skilled workers from overseas as permanent residents. Many other developed countries employ similar practices. By the same token, discouraging a "brain drain" is a pro-HC policy (Cheatham, 2020).

Similarly, internal migration can influence the distribution of dependency ratios and of $\mathrm{HC}$ and its benefits across communities, shaping centers and peripheries, both geographically and socially.

\section{B}

\section{The Human Capital}

Schultz (1961) and Becker (1994) pioneered the formal economic theory of human capital (see also Kwon, 2009). The theory focused on investment in the individual's knowledge and skills, mainly through schooling and on-thejob training. These have remained the leading research topics in $\mathrm{HC}$ theory. Simultaneously, this theory provided the foundation for understanding an individual's migration or relocation of economic activity, as well as health care (mainly medical care), as investments in HC. These elements, respectively, gained prominence in the studies of Harris \& Todaro (1970) and Grossman (1972). ${ }^{1}$

Frank \& Bernanke (2007) recognize human capital as "an amalgam of factors such as education, experience, training, intelligence, energy, work habits, trustworthiness [social capital], and initiative that affect the value of a

1 These works can be conceptually and methodologically incorporated in the original works, especially when we, arguably, consider productivity and well-being as almost synonymous. 
worker's marginal product" or productivity. It also relates to his or her jobseeking and employment opportunities (Greider, Denise-Neinhaus, \& Statham, 1992; Vinokur et al., 2000). Rastogi (2002) conceptualizes human capital as "knowledge, competency, attitude and behavior embedded in an individual." Other researchers define human capital as "the knowledge, skills, competencies and attributes in individuals that facilitate the creation of personal, social and economic well-being" (Rodriguez \& Loomis, 2007).

Schultz (1961) defined human capital as the productive capacity of human beings, mainly associated with knowledge and skills, and he and Denison (Schultz \& Denison 1962) pointed to it as a key factor in the growth of the modern economy. However, there remained an "unexplained" residual gain in productivity and income growth that could not be attributed only to measurable knowledge and skills as such. Others attempted to clarify how human capital can contribute to sociopolitical development, stability, and freedom (Alexander, 1996; Grubb \& Lazerson, 2004; Sen, 1999), which in turn contribute to productivity and income growth. Consequently, a considerable literature has developed to supplement income per capita as the defining metric of well-being (see, e.g., Mishra \& Nathan, 2013). Among the most celebrated metrics is the Human Development Index (HDI), which is calculated using normalized indicators from three dimensions: education, health, and standard of living (or income) (Mishra \& Nathan, 2013), closely resembling the above-mentioned dimensions of human capital.

\section{- Education and Training - Knowledge and Skill}

Research in this area has focused on the individual's instrumental acquisition of knowledge and skill through formal and on-the-job training. Most scholars refer to the possibility of increasing individual income as a result of an increase in the individual's productivity, through investment in schooling and training in order to acquire market-oriented knowledge, skills, and abilities (Becker, 1994; Denison, 1962; Schultz, 1961; Sidorkin, 2007; Garavan et al., 2001; Youndt et al., 2004). From the point of view of economic theory, productivity has to do with measurable market income for the individual and income per capita for the

8 | Sustainable Well-Being in Israel 
economy. Analyses of the role of knowledge and skill acquisition have invariably been accompanied by measurement of the private and social rates of return on the investment. ${ }^{2}$

This approach has not been free of criticism by its own standards. Formulations focusing on formal education have overlooked human capital formation in early childhood, which may explain considerable variations in personal abilities, including those that have "market value" (Reynolds et al., 2010; Schoellman, 2016; Rolnick \& Grunewald, 2003). Vaknin, Shavit, and Sasson (2020) examined the intergenerational human capital and income disparities associated with early childhood capital formation.

Critics have pointed out the strictly economic and instrumental measures used in human capital theory: increased productivity and higher wages or incomes. Conceptualizing the education and training element of human capital only as an economic investment pushes us to view it as straightforwardly comparable with other, alternative types of investment. Thus, a family might compare the rate of return on an investment in human capital with the returns on other investments it could make, and would invest in human capital only if that investment offered the highest return. From this perspective, issues of culture, gender, identity, emotions, history, and so forth are largely overlooked.

Furthermore, the widespread $\mathrm{HC}$ theory focuses on formal and on-the-job training, at the expense of informal aspects, such as life skills relating to social interactions, or an individual's life-long "training," although these may gain prominence in a world of fast-changing technology.

The validity of these criticisms does not, however, imply that we should do away with the prevailing approach; rather, they prompt us to recognize that there is more to human capital than productivity measured in the strict terms of economic outcomes. As Sen (1997) puts it, "we must go beyond the [prevailing] notion of human capital, after acknowledging its relevance and reach. The broadening that is needed is additional and cumulative, rather than being an alternative to the 'human capital' approach."

2 The social rate of return applies when the individual's investment is subsidized. 
Indeed, the approach taken in the present discussion is that human capital is also a "consumption commodity," with intrinsic values to the individual and society. The benefits, such as those associated with self-esteem and good health, are hard to quantify, although their significance to human welfare is high and may increase as human and physical capital are blended with artificial intelligence and robotics, increasingly rendering the "human" an agent of consumption rather than just of production However, since the instrumental benefits of income growth ensuing from human capital, and any consumption benefits, are assumed to be closely and positively associated (or correlated), the measurement of income benefits can be used as a proxy measurement to represent all the benefits of $\mathrm{HC}$ enhancement, at least for comparative purposes. At the same time, care must be exercised in comparing aggregate measures that overlook various aspects of human capital and income distribution.

\section{- Training Infrastructure}

Possibly because $\mathrm{HC}$ theory at least originally had its roots in the USA, relatively little attention was paid to the role of pertinent infrastructure and public involvement. While wage and related HC differentials between, say, whites and blacks have been recognized, the lack of a welfare-state approach and of concern for inequalities may have diminished concerns about equal opportunities, especially for the weaker segments of the population.

Clearly, HC formation depends critically on the availability of formal and informal training institutions at all levels, as well as of adequate and qualified training personnel. Both institutions and personnel must be adaptive to the fast-changing technology and circumstances of our times.

\section{- Location and Diversity of Economic Activity}

An individual's migration decisions and eventual location of residence and economic activity can be regarded as an extension of their search for gainful employment and self-esteem. This activity can be localized as well as global, depending on drive, resources, migration restrictions, and job opportunities

10 | Sustainable Well-Being in Israel 
(Carrillo-Tudela, 2012). Mobility (as well as market transferability of skills) is a major component of $\mathrm{HC}$.

Harris and Todaro (1970) recognized migration as an element of human capital, in that it can further enhance the productivity of that capital, whether it is still in formation or already acquired. Like job-searching, migration has costs and returns that can be accommodated conceptually in $\mathrm{HC}$ theory.

Indeed, migration of both skilled and unskilled labor - including both internal migration, mainly from rural to urban areas, and migration across national borders - is a key aspect of modern life and the global economy. Modern technology has recently made a "physical move of HC" less necessary for job migration. This possibility raises interesting questions about the distribution of the benefits of $\mathrm{HC}$ between people's location of residence and the location of their economic product.

Internal migration, unless restricted (as it is, for example, in China), is generally less demanding and more natural than cross-border migration. It can be a source of regional disparities and can also, simultaneously, fuel them, potentially creating challenging disparities in the formation of national human capital and its rewards. In other words, internal migration can shape the distribution and hence the overall impact of national human capital.

Location of economic activity associates with employment opportunities that provide people with diversity and choice, also about their use of leisure time, therefore generating utilitarian aspects beyond securing gainful and fulfilling employment. These elements may be increasing in value both for the young and for the aging population, which increasingly blends retirement with work.

\section{- Health}

Grossman (1972) defines "health capital" as the "stock" of health with which an individual is endowed, which depreciates over time due to the aging process, but may be maintained or improved by investment. Investigating the impact of health capital disaggregated by gender on economic growth in a sample of 210

11 | Sustainable Well-Being in Israel 
countries over the period from 1990 to 2008, Arusha Cooray (2013) suggested that the influence of health capital across countries cannot be generalized. Disaggregated by income group, the results reveal that health capital has a robust positive influence on economic growth in high and upper-middle income economies. In low and low-middle income economies, by contrast, health capital gains are statistically significant only through their interaction with education and health expenditures. Increased fertility rates reduce the influence of health capital on economic growth, a view supported by Bhargava et. al. (2001).

Indeed, high income, education, and good health are closely related and synergetic, rendering disentanglement of their impacts a challenge. In general, higher income (especially in developing countries) leads to better health through its effects on the availability of adequate shelter (including sanitation), on nutrition, and on access to medical care, among other things. In turn, better health, by increasing productivity and longevity, enhances learning and income (e.g., Preston, 1975; World Bank, 1993; Pritchett \& Summers, 1996). Nonetheless, the complementarities and interactions between investment in health and education have been challenged in the human capital literature, at least conceptually.

An increase in survivorship at later ages raises the returns from investments in education, because educational costs come at earlier ages and returns at later ages (Becker, 1994; Usher, 1973; Meltzer, 1974; Ehrlich, 2000). Evidence indicates that more educated persons take better care of their health, even within a given spending framework on medical care, by visiting better doctors, greater compliance in taking prescribed medicines, eating more nutritious diets, and in many other ways. This suggests that an increase in schooling raises life expectancy, and that education's positive effects extend beyond jobs and earnings (Mirowsky \& Ross, 1998). Education enables people to coalesce healthproducing behaviors into a coherent lifestyle, provides a sense of control over outcomes in one's own life, and helps parents inspire a healthy lifestyle in their children.

At the societal level, health is one of the many factors (such as initial per capita income level, geographical location, environmental and economic policies, and investments in education) that have a significant effect on subsequent

12 | Sustainable Well-Being in Israel 
economic growth. Mushkin (1962) was the first to recognize health as an investment that contributes to the economy. Other work followed, with attempts to establish the impact of changes in health levels on the productive capacity of the economy (Klarman, 1965; Fuchs, 1972). These early studies tried to establish how many more people are made available for work as a result of a decrease in death rates, or the present value of future potential production as a result of lives saved. Related work was concerned with the increase in per capita productivity brought about by, say, reducing absenteeism from work (Roberts, 1959).

Bloom and Canning (2000) argued for the need to understand the mechanisms through which health impacts income. The most obvious mechanism is the effect of health on the productivity of workers. If health improves productivity, a relationship between health measures and wages is to be expected, since the extra productivity of healthy workers ought to be reflected in their remuneration. Bloom and Canning $(2000,2003)$ took a comprehensive view of health as human capital and of its singular impact on economic performance. They noted the following potential contributions of health to the economy:

- The prospective lifespan of healthier workers is longer, and long lifespans increase the need for retirement income. In developed countries, savings for retirement are the main source of investment funds. Increasing longevity thus may set off a savings and investment boom.

- Health can be a complementary input to other forms of human capital. Productivity and wages rise with education levels and worker job experience. These returns may be higher for healthy workers, such that the gains from education and work experience accrue mainly to healthy workers who remain at work.

- Reductions in mortality rates change the age structure of the population. Initially, health improvements tend to reduce the mortality rates of infants and children, causing a "baby boom" cohort, which can have profound effects on the economy as that cohort enters into education, works as young adults, works and saves as older adults, and finally enters retirement.

13 | Sustainable Well-Being in Israel 
Estimates suggest that the health effect on Gross Domestic Product (GDP) is considerable: One extra year of life expectancy raises steady-state GDP by about four per cent. This health effect has been estimated consistently in several studies (e.g., Barro, 1996, 1997; Barro \& Sala-i-Martin, 1995; Bhargava et al., 2001; Bloom, Canning, \& Sevilla, 2001; and Hamoudi \& Sachs, 1999).

Grossman (1972) was the first to model an individual's optimal investment in health or increasing longevity similarly to investment in schooling as a means to increase productivity or earning per year of working life. At the same time, he recognizes the "consumption" attributes of good health, so that measuring the rate of return on the investment simply by its effect on market productivity would be an underestimate. Related work concerning the value of life analyzed how much people are willing to pay for improvements in their probabilities of surviving to different ages or reduce their probability of dying (e.g., by purchasing new tires, smoke detectors, etc.; Usher, 1973; Jones-Lee 1976; Rosen, 1988; Murphy \& Topel, 2006).

Arrow, Dasgupta, and Mumford (2014) sum up:

- Health is an essential characteristic of human well-being.

- Health capital is an important component of inclusive wealth.

- The economic model of health capital shows how health affects human well-being through three distinct channels: direct well-being, productivity, and longevity.

- Most health services influence human well-being directly rather than through the production of goods and services that are counted in the GDP.

- In the absence of better estimates of the direct and productivity effects of health capital, gains in quality-adjusted life expectancy should be used as its primary measure.

Regarding the last point, however, it is increasingly recognized that staying alive does not always mean that the individual retains the full capacity to function effectively or that he or she enjoys quality of life to its full potential.

14 | Sustainable Well-Being in Israel 
Consequently, since the 1990s, three further metrics have been developed to consider a year of life by its quality (Chernichovsky and Bowers, 2014): healthy life years, disability-adjusted life years (DALYs) and quality-adjusted life years (QALYS).

\section{- Health and Medical Infrastructure}

For similar reasons to those relating to training, the need for a public approach to diverse health and medical needs and opportunities was largely overlooked in the original HC literature. Policy discourse, however, has pointed to the critical importance of preventive care - including education and training for healthy lifestyles and habits, concern for hygiene, vaccination and screening uptake, seatbelt and bicycle helmet usage, smoking cessation, healthy diet, and family self-care - especially as sedentary lifestyles, obesity, and their consequences have reached epidemic proportions. The aging population poses increasing challenges associated with long-term care, including psychological support, end-of-life care, and dealing with loneliness, which is a rising health risk. Here again, environmental, educational, and medical infrastructure interventions, including, for example, elderly-friendly cities, as well as adequate care-giving staff, are required for lifelong (re)training and care.

15 | Sustainable Well-Being in Israel 


\section{Human Capital in Israel}

$\underline{A}$

\section{Demography}

Israel's current population growth rate of around $2 \%$ is about three times higher than the average for countries in the Organization for Economic Cooperation and Development (OECD). It is fueled by both aspects of population growth natural fertility and immigration - combined with low age-specific mortality rates. An implicit pro-fertility policy, an explicit pro-immigration policy, and high and fairly equitable standards of living, combined with universal access to quality medical care, have all contributed to this situation.

\section{a Fertility}

Israel's Period Total Fertility Rate (TFR) in 2015 was 3.1, an unusually high value among OECD countries, of which only Mexico and Turkey meet the population replacement level of 2.1. Moreover, compared with other developed and even transitional economies, relatively educated secular families, who make up the largest share of all Israeli families $(74 \%)$, are having more children than their counterparts in other countries, and a higher percentage of children are born to older and more educated parents (Weinreb, Chernichovsky, \& Brill, 2018).

While there is no explicit pro-fertility policy, child allowances in Israel are not means-tested and are clearly pro-fertility. They probably have the highest 
relative impact among low-income and high-fertility groups, notably Haredi (ultra-Orthodox) Jews.

\section{- International Migration}

An explicit pro(-Jewish) immigration policy has been an existential pillar of the State of Israel. The Law of Return opened the country's gates to all Jews unconditionally, regardless of gender, age, and labor force productivity potential. Thus, while migration of Jews (aliyah) has been driven by exogenous shocks (such as the breakup of the Soviet Union), active absorption of immigrants has been a policy priority. The contribution of immigration to Israel's population growth dissipated by the early 2000s, after the waves of immigration from the FSU died down.

Over the period from 1960 to 2017, immigration annually contributed, on average, $0.93 \%$ out of Israel's average total population growth rate of $2.51 \%$ per annum. In view of the country's geopolitical situation, the sheer numbers mattered to the absorbing population, which showed its willingness to invest in the newcomers' settlement and initial needs. That investment is expressed in borrowing and national debt policies directed toward financing both physical infrastructure and human capital formation to support the newcomers. Thus, the absorption process has contributed to physical (including labor) factor growth, irrespective (for the moment) of productivity growth ensuing from the increment of knowledge and skills.

Razin (2018) suggests that aliyah added massive investments, both in residential structures and in non-residential capital. These investments were so substantial that they increased the capital-to-labor ratio and facilitated economic growth. Razin further notes that, in general, the massive investments in physical capital and infrastructure were financed by capital imports (reflected in persistent national current account deficits), as the newcomers themselves had fled their former homes almost penniless and were credit-constrained.

17 | Sustainable Well-Being in Israel 


\section{- Dependency Ratios and Demographic Dividend}

Weinreb (2020a) projects that Israel's population will increase from around 9.1 million in 2020 to approximately 12.8 million in $2040 .{ }^{3}$ He also projects that until the mid-2030s, there will be rapid growth in the over-70 age cohort, and until about 2027, the number of young children will increase at a much slower rate than has been the case over the last decade; thus, Israel is now entering a period with a relatively large cohort in its peak earning years.

The excess size of cohorts in their early 30s, in addition to those in their late and mid-20s, can act as a demographic dividend, supporting the aging population and human capital formation among the young - assuming continued high rates of employment, and rising labor-force participation in the Arab and Haredi sectors in order to boost Israel's current low productivity (see below).

Together, these projected age-distribution changes will modify the child- and old-age dependency ratios over the next 20 years. Israel currently has the highest combined total child- and old-age dependency ratio in the OECD: For every 100 working-age adults in 2019, there were 60 children aged 0-17 and 21.7 people aged 65 or more. Weinreb suggests that this total dependency ratio will continue to increase over the next several years, peaking at around 60.2 children and 24.2 elderly per 100 working-age individuals in 2026, before stabilizing and falling marginally by 2040. By that time, reductions in the child-dependency ratio (to 56.3 children per 100 working-age adults) will have outweighed ongoing increases in the old-age dependency ratio (to 27.5 elderly per 100 working-age adults). However, the dependency ratios are expected to remain remarkably high, despite the fall in child dependents outweighing the rise in elderly dependents.

While these last data might suggest a negative demographic dividend, that depends on the investment in these children's HC. Current high fertility, especially among secular populations endowed with $\mathrm{HC}$, can be a key strategic asset for Israel if it can secure investment in these children's future productivity.

3 Israel's dependency ratios are skewed by military service, which delays the entry of young cohorts into the labor force.

18 | Sustainable Well-Being in Israel 


\section{- Internal Migration}

Internal migration in Israel is considered here in the context of regional disparities in variables associated with inequalities in $\mathrm{HC}$ and opportunities for its formation. Figures 1 and 2, respectively, show the association between the Socio-Economic Index (SEI) of cities with populations of over 50,000 4 and their residents' educational achievements (as measured by the number of individuals entitled to a matriculation certificate) and average life expectancies. ${ }^{5}$

\section{Figure 1: Association between the 2015 Socio-Economic Index (SEI) and percentage of individuals eligible for a matriculation certificate in localities in Israel.}

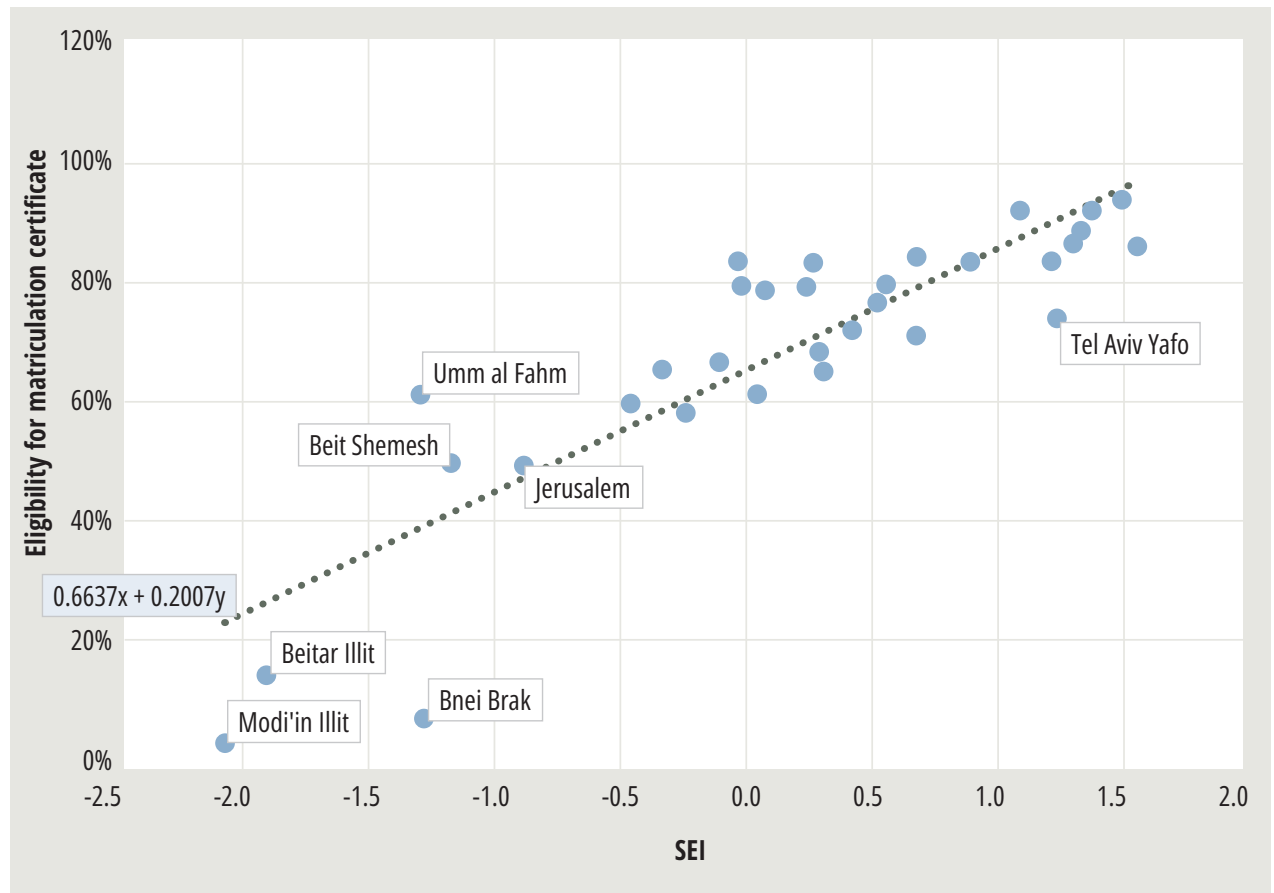

Notably, Haredi communities have the lowest SEI and educational scores but nevertheless do well on life expectancy. This enigma is dealt with by Chernichovsky and Sharony (2015).

4 As suggested below, within the Jewish population, the smaller communities, especially of non-Haredi Jews, tend to be relatively affluent.

5 The SEl is based, among other things, on HC indicators, so that there is by definition a correlation between the two, but disparities nevertheless remain. 
Figure 2: Association between life expectancy (2013-2017) and the 2015 SocioEconomic Index (SEI) in localities in Israel.

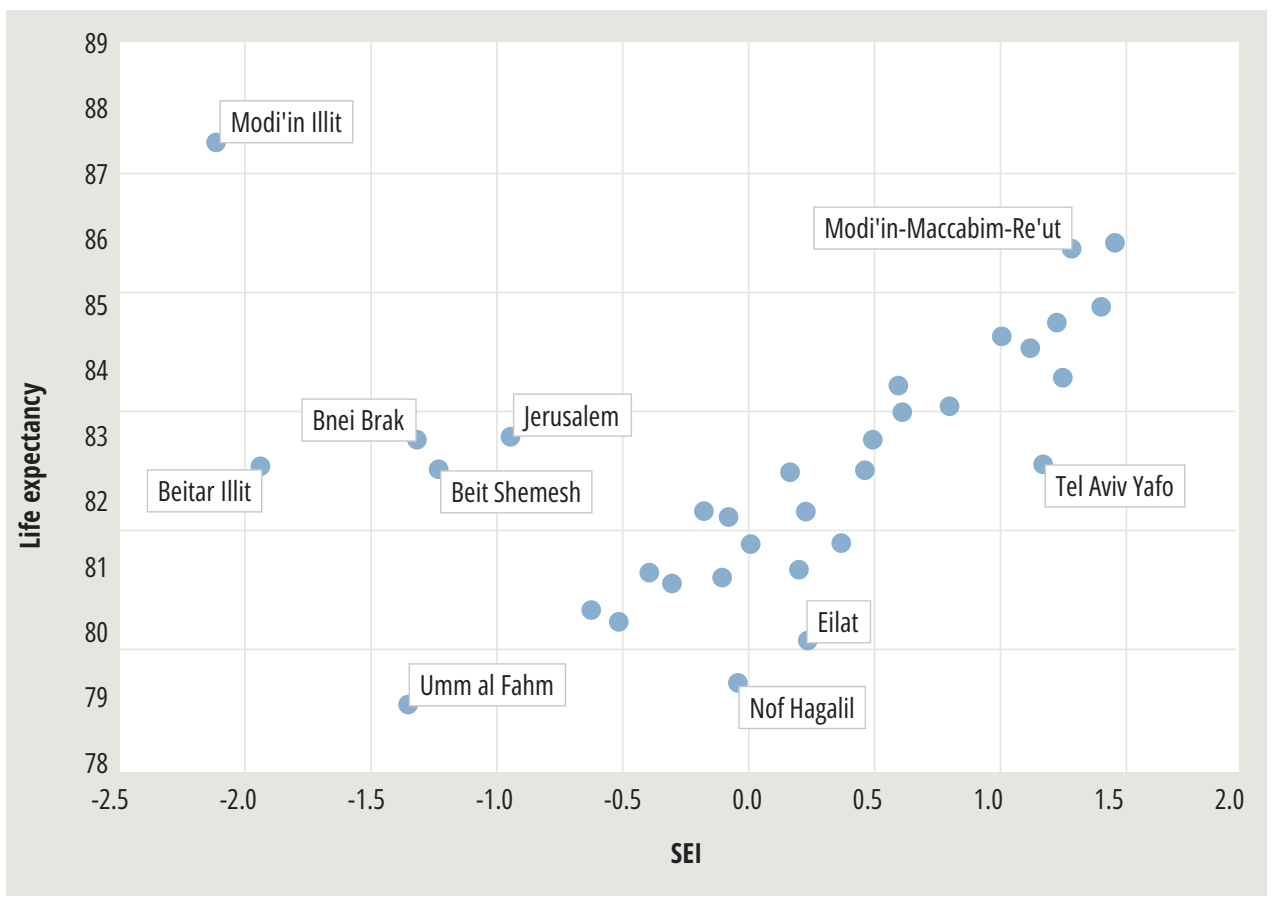

In Israel, internal migration in recent years has generally been from larger, more urban localities to smaller towns and rural communities. For the period from 2016 to 2019, the immigration balance was negative in all localities of more than 200,000 residents - Jerusalem (which declined at an annual rate of 7.4 inhabitants per 1,000 during this period), Ashdod, Beer Sheva, Haifa, Netanya, Petah Tikva, Rishon LeZion, and Tel Aviv - while localities of 2,00099,999 inhabitants and rural localities grew in population size. The change has not been uniform for medium-sized localities with populations of 100,000199,999 inhabitants: The average migration balance was positive in the cities of Ashkelon, Ashdod, Beit Shemesh, Bnei Brak, Rehovot, and Ramat Gan, as well as in the new towns of Elad, Beitar Ilit, and Modi'in Ilit, and negative in the cities of Bat Yam, Holon, and Kfar Saba.

Older data from the years 2003-2005 (Demographic Characteristics of Internal Migration 2003-2005), corroborated by more recent 2015 research (Rebhun \& Brown, 2015), suggest that young people are the cohort that migrates most frequently. For example, in 2005 about $44 \%$ of the internal migrants were young 
adults aged 20-34, and another $24 \%$ were children up to the age of 14 , the children of those young adults. The median age for internal migration in 2005 was 27 (Demographic Characteristics of Internal Migration 2003-2005).

Internal migration in Israel is more common among Jews than among Arabs. Ninety-five percent of the internal migrants in those years were Jews, who comprise about $80 \%$ of the total population. Internal migration of Arabs occurred mainly as a result of marriage and was more frequent among women than among men.

The human capital ramifications of these data are not obvious, but some general conjectures or hypotheses can be offered. The growth of Ashkelon, Beit Shemesh, Bnei Brak, and newer localities such as Elad, as well as the secular out-migration from Jerusalem, is associated with the growth and clustering of the relatively low-income Haredi communities. This phenomenon associates with their high fertility rates, on the one hand, and their need for low-cost housing, on the other. Similarly, we observe clustering of the Arab population in growing Arab towns.

Thus, while the overall spread across localities, mainly of the non-Haredi Jewish population, probably contributes to some equalization of $\mathrm{HC}$ in that population, the clustering of the so-called "tribes" - Haredi Jews, Arabs, and non-Haredi Jews - can signify growing inequality between them. Human capital challenges and related income consequences within the Haredi population, combined with high dependency ratios, lead to it becoming even more clustered, on the one hand, and to spread out, on the other. Thus, both the geographical center and the periphery in Israel will increasingly have a "tribal" dimension. These developments contribute to the widening of existing disparities and social segregation in Israeli society. Meanwhile, the out-migration of non-Haredi young populations from the cities and larger towns may strengthen the geographical periphery.

21 | Sustainable Well-Being in Israel 


\section{Education and Training - Knowledge and Skill}

Compared with OECD countries, Israel is still well endowed with educationrelated human capital, which has contributed to income, welfare, impressive economic growth, and its standing as a "startup nation." Demographic developments put this standing at risk.

In $2018,48 \%$ of $55-64$ year-olds Israelis had a tertiary education, compared to only $27 \%$ on average across the OECD countries (OECD, 2019). This group enjoys good labor-market prospects in Israel: In 2018, the unemployment rate for tertiary-educated adults was $4 \%$ in Israel, compared to $6 \%$ on average across OECD countries. ${ }^{6}$

However, Israel's historically above-average share of tertiary-educated adults is losing ground among younger adults. The difference between Israel and the OECD average among 25-34 year-olds is narrow: 48\% in Israel, compared to $44 \%$ across OECD countries. These cohort differences, and the deterioration in Israel's relative standing by this indicator, can be associated with the impact of immigration and emigration (see below) and changes in the proportions of the three main Israeli "tribes": Ultra-Orthodox Jews, Arabs, and non-orthodox Jews.

Weinreb (2020b) notes that Israel's educational advantage over other OECD countries has evaporated over the last few decades. He shows that in a population growing as rapidly as Israel's, even the most modest aspirations demand investment and expansion. For example, merely maintaining current levels of enrollment in Israel's higher education system will require around a $50 \%$ increase in the number of places in Israel's universities and colleges by

6 Military service in Israel affects international comparisons of the enrollment rates of young adults in higher education. About $70 \%$ of Israelis leave off their education between the ages of 18 and 24 , the highest rate across OECD countries, but a large share enters post-secondary programs at ages 21-23, following the conclusion of their military service, at around the same time that their foreign counterparts are completing their degrees.

22 | Sustainable Well-Being in Israel 
2040. Raising educational levels among Arab and Haredi students will demand even greater expansion of the higher education system.

This reality, combined with the impact of demography on the potential future labor force, paints a relatively bleak outlook. According to the medium scenario of Israel's Central Bureau of Statistics (CBS), the ultra-Orthodox sector is expected to comprise $26 \%$ of the working-age (25-64) population by 2065 , compared to only $7 \%$ in 2015 (Figure 3 ). ${ }^{7}$ That is, contrary to the trend in the Arab population, the segment of the Jewish population with low HC and low labor-force participation rate is rising steadily. Ben-David (2017-2018, 2019) argues that unless there is a drastic policy change, an already impoverished population will become larger and more impoverished, and overall productivity may fall below sustainable levels.

Figure 3: Projections of Working Age Population - 25-64. Israel 2015-2065

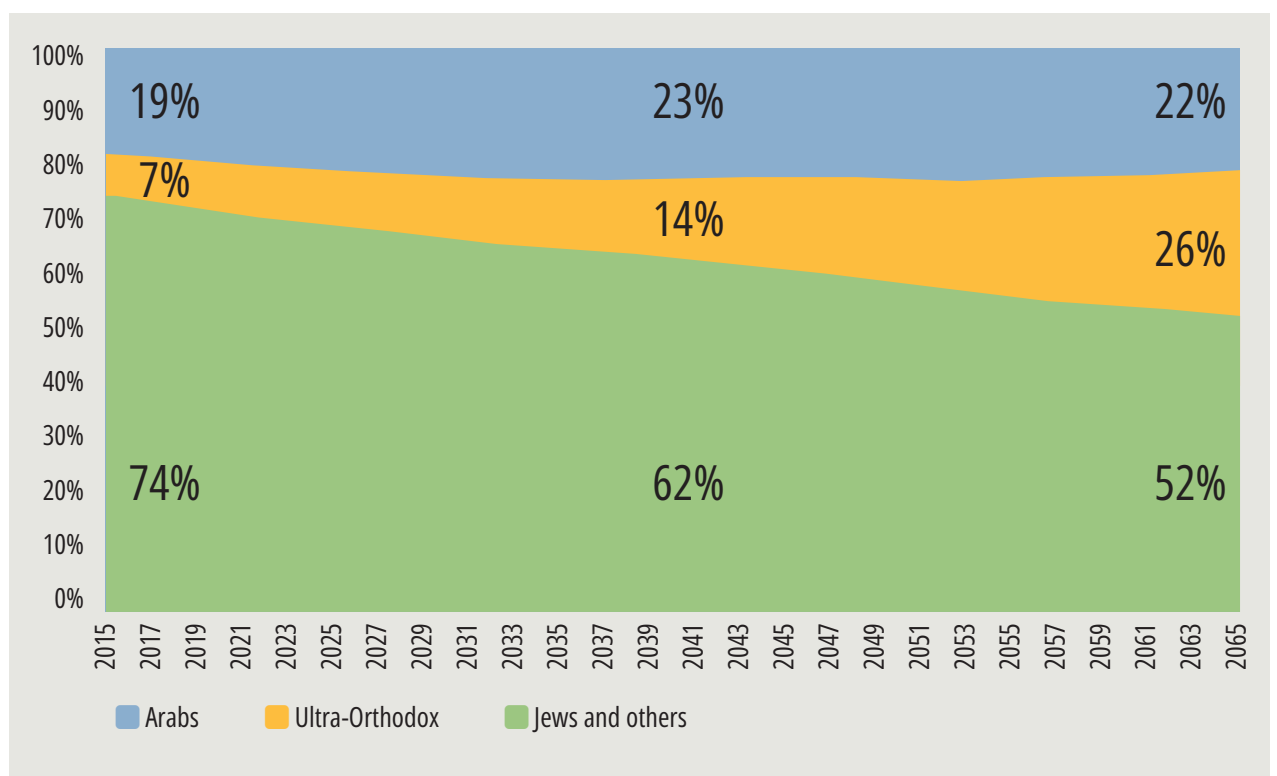

Source: Population forecast (medium projection), Central Bureau of Statistics, 2017.

7 Weinreb and Blass (2018) argue, on the basis of rates of attrition from Haredi schools to other schools, that the CBS projections may be inaccurate. However, the rates of attrition are not sufficient to change the overall trend.

23 | Sustainable Well-Being in Israel 


\section{Migration, Knowledge, and Skill}

Net migration has also contributed to Israel's knowledge and skill capital since before statehood. Razin (2018), focusing on the wave of immigration from the former Soviet bloc in the early 1990s, notes that it was heavily skewed toward high education levels. New immigrants averaged 14.0 years of schooling, compared to the national average of 13.3. Even more striking was the percentage of heads of households with first degrees: $41.1 \%$ among the new immigrants, compared to a national average of just $29.5 \%$. Presumably owing to their higher education levels and smaller family sizes, the average labor income per person among the new immigrants between 1990 and 2011 (at 2011 prices) was NIS 4,351 , compared to a national average of only NIS 4,139, even though the new immigrants had less work seniority than the established population.

However, despite being a developed country and benefiting from educated and skilled immigrants, Israel suffers from a relative brain drain. Gould and Moav (2007) showed that the probability of educated individuals (with a first degree or higher) emigrating from Israel was 2.5 times greater than for those with less education. A similar pattern exists for new immigrants to Israel, although the magnitudes are greater, and the relationship between education and the probability of leaving Israel is more pronounced. Gould and Moav noted several key reasons for this brain drain:

- Inflexible labor market: A large number of Israel's educated new immigrants, mostly from the former Soviet Union, eventually moved away, not just to more developed Western countries but also back to Russia, although Russia is much poorer than Israel. That is because Russia, unlike Israel, has a flexible labor market that rewards successful workers and encourages risktaking by budding entrepreneurs.

- Archaic kibbutz system: Kibbutz members refused to adapt to changing times, causing a massive desertion of their best young people. Kibbutz 
veterans, who relied on the younger generation's support, found themselves destitute.

- Large unproductive population: In Israel, a small population of workers supports a large population of children and non-working adults, to an extent unheard of in other developed countries. Educated people bear the burden by paying a disproportionate share of taxes, which are spent supporting the families with non-working adults.

\section{E}

\section{Health, Welfare, and Productivity}

\section{- Life Expectancy}

In 2019, life expectancy at birth in Israel ranked tenth in the world, at 82.9 years. ${ }^{8}$ This represented an increase of 11.1 years over the figure for $1970,71.8$ years - an increase of about 2.9 years per decade. ${ }^{9}$

Compared with other countries, the gender gap in life expectancy is narrow in Israel. Israeli men rank 7 th in the world in terms of life expectancy; women - 11th. Arabs in Israel fare worse than Jews: Although women's and men's life expectancies at birth rose for both Jewish and Arab Israelis over the past two decades, life expectancy disparities between the two populations are not declining for women and are increasing for men. Women in both populations show an annual increase of a quarter of a year in their life expectancies, but a four-year gap persists. For men, the picture is quite different: The life expectancy gap between the two populations, which was 1.5 years in 1996-1997, widened to four years in 2015 (Chernichovsky et. al., 2020).

8 https://www.cia.gov/library/publications/the-world-factbook/fields/355rank.html.

9 Unless otherwise specified, data are from the Israeli Central Bureau of Statistics website: https://www.cbs. gov.il/he/pages/default.aspx.

25 | Sustainable Well-Being in Israel 
A baby born in 2015 in Israel was expected to live, on average, 71.7 years in good health (or $87.4 \%$ of its life) - about 10.4 years less than its total life expectancy. Israel ranks 10th in the world on this indicator of the quality of life. While many developed countries are seeing their total life expectancy grow faster than their health-adjusted life expectancy (HALE), that gap seems to be greater in Israel. Between 1990 and 2015, HALE in Israel grew at a rate of almost half a month per year more slowly than the growth in overall life expectancy. By comparison, among fifteen countries in the European Union, the median difference between the two growth rates is about a third of a month (0.33; Bowers \& Chernichovsky, 2017).

Israel's relatively good standing in terms of total life expectancy is a result of both a low rate of infant mortality and low rates of age-adjusted mortality in diagnoses of malignancies, and especially heart disease. Particularly with regard to mortality in these two diagnostic categories, Israel's relative status is better than those of the United States and of fifteen countries in the European Union. By contrast, diabetes and kidney-related mortality rates are higher in Israel than in those countries (Chernichovsky, 2020).

When looking at the picture of health and its causes in terms of disabilityadjusted life years (DALYs), a different picture emerges than that based only on mortality. Israel's standing in DALYs in relation to heart disease, strokes, and even dementia is relatively good, though it is inferior in relation to headaches and diabetes.

Average gains of about $0.3 \%$ annually in longevity for the period from 1970 to 2018 have been accompanied by average gains in GDP per capita of about $2.0 \%$ per annum. ${ }^{10}$ That is, GDP per expected year of life increased by about $1.7 \%$ annually, suggesting that the increase in longevity over the said period was accompanied by an increase in productivity per average expected year of life.

10 Work is underway to establish how the gains in life expectancy over time translate into an increase in the 25-65 age cohort, representing the bulk of the labor force.

26 | Sustainable Well-Being in Israel 


\section{- Labor Productivity}

Gains in productivity may have followed extensions of life in the labor market, but they have not translated into labor productivity, relatively speaking. Labor productivity is defined by the product per hour worked - that is, the total product of the economy divided by the total number of working hours. Labor productivity in Israel is low compared with that in the OECD. From $\$ 33.4$ per hour of work in 2000, it rose to $\$ 42.3$ per hour in 2019 , an increase of about $27 \%$. In the same period, labor productivity in the OECD rose at a similar rate, from $\$ 43.3$ to $\$ 54.5$ per hour, an increase of about $26 \%$. Thus, since the early 2000 , the gap between labor productivity in Israel and in the OECD has remained constant, in the range of $73 \%-77 \%$.

Among the factors that affect labor productivity are the human capital of the workers, the physical capital in the economy, and total productivity, which includes, among other things, the adaptation of regulation in the country to the needs of the economy.

Labor productivity in the Israeli economy is not uniform across industries. It is high in export industries (including high-tech industries) and relatively low in local industries (trade and services). This is common in the developed world, but in Israel the gap is particularly wide, as worker skills in local industries are relatively low.

With regard to physical capital, the gaps are reflected in relatively low investment rates as a proportion of GDP in the Israeli economy and less developed infrastructures than in OECD countries. As for overall productivity, one may point to areas in which Israeli regulation has not adapted to the needs of a competitive market, and to the large gap between the number of annual vacation days enjoyed by kindergarten and primary school students and those of working parents.

Israel's low productivity is also partly explained by some distinctive characteristics of its economy. The security situation requires the government to invest considerable resources in defense spending, at the expense of 
potential spending on infrastructure and investment in human capital. Security instability also raises the risk premium for investment in the Israeli economy, and compulsory military service delays the acquisition of academic education and entry into the labor market by several years.

Figure 4. Labor productivity per hour in the OECD and in Israel, 2000-2019

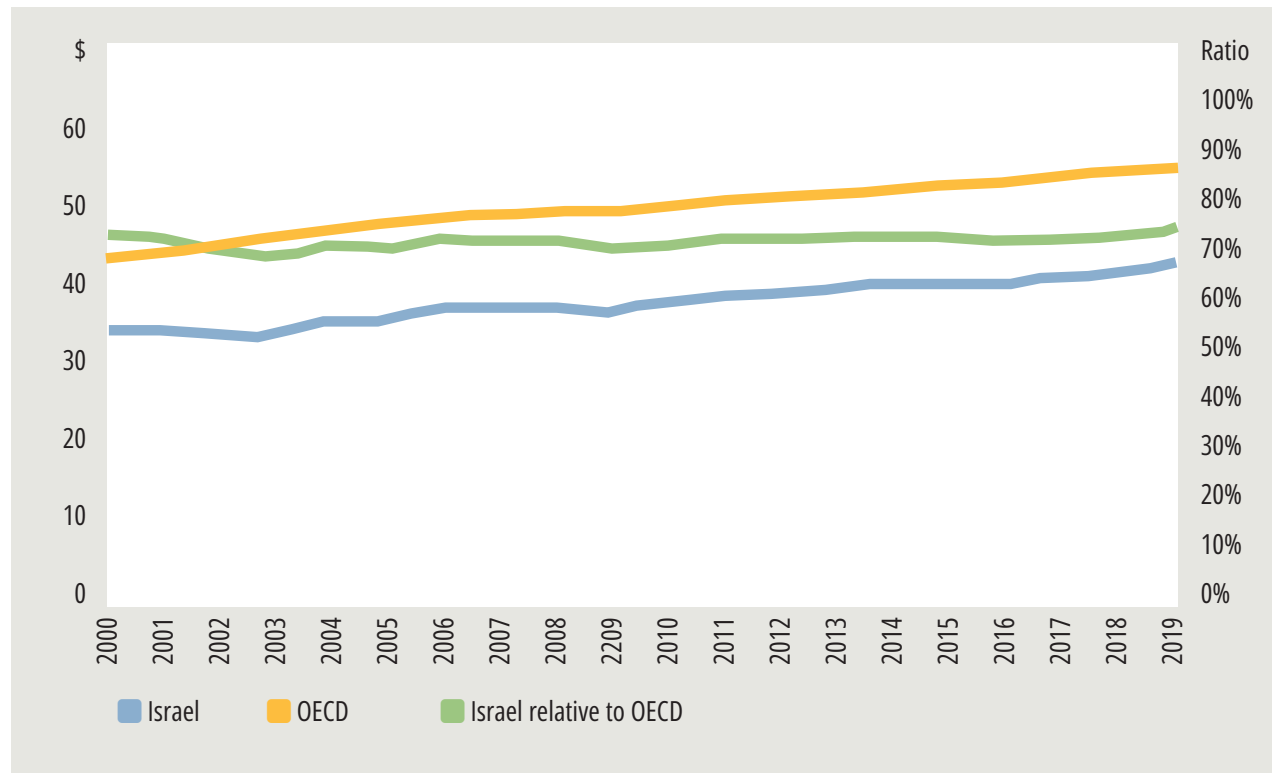




\section{Conclusion and Policy Recommendations}

Israel has benefited from rapid economic growth and related well-being, as a result of comparatively high levels of human capital formation, with robust population growth enhanced by migration, knowledge, skill, and health. Israel's achievements in this regard are impressive, especially considering the meager natural resources at its disposal (until recently) and the low levels of secular education and $\mathrm{HC}$ in its Haredi and Arab populations. The latter have been key sources of low labor productivity.

However, Israel suffers from low productivity compared with the OECD and is at risk of losing its edge, especially in view of the declining net immigration of skilled labor, the high and increasing dependency ratios, and the growth of the Haredi population, whose males are relatively inactive in the labor market and lack relevant training. The country must make deliberate efforts to augment its investment in all aspects of human capital, so as to increase labor-force participation rates, productivity, and welfare.

\section{A}

\section{Population policy}

Israel's contentious child-support policy must try to strike a balance between income support and pro-natal incentives, which may be inconsistent with HC 
formation and income growth, especially in the Haredi population. High fertility rates in the secular population should be supported by investment in early childhood development, including subsidized childcare for working mothers. This source of population growth could produce Israel's real demographic dividend, notwithstanding the concept's prevailing definition as involving a decline in fertility.

While Israel's liberal immigration policy for Jews has facilitated huge waves of immigration, these were largely driven by events overseas. Waves of the kind Israel benefited from soon after the establishment of the state and following the breakup of the Soviet Union are unimaginable nowadays. Consequently, Israel needs to encourage immigration, especially of skilled labor, by relaxing regulations in the labor market. Recently, a sound policy in this regard was instituted regarding the licensing of overseas-trained physicians (Tur-Sinai et al, 2020). Less unionized and less uniform wages that are internationally competitive may help, but this must be matched by appropriate funding, in the case of MDs, of the healthcare system, as discussed below. Such a policy would reduce incentives for emigration. State support of high-tech industries and infrastructure in general will help.

\section{B}

\section{Schooling and training}

Israel's formal education challenges are formidable, particularly if it is to maintain its edge as a highly educated nation, in the face of the brain-drain and the relatively high natural growth rate of the Haredi and Arab populations. Investments in all aspects of education, including early childhood development, will have to increase.

Blass (2020) proposes to reduce gaps while improving academic achievement and the economic management of the education system. His recommendations include: 
- A differential basket of services for the student, depending upon his or her background (except in special education). This approach could help the Haredi population make up gaps in secular studies.

- Wage increases for teachers. These would include an across-the-board wage increase for "regular" teachers and unique salary increases for those working with students from poorer backgrounds and for excellence in teaching.

- Dropout prevention. To be achieved by adding benefits for institutions that accept students who have been defined as dropouts from post-primary education; strengthening educational frameworks to support students at risk of dropping out; and rewarding institutions that retain students, while taking harsh measures against those that do not act in accordance with procedures aimed at doing so.

- Legislation of a Right to Education Act. The Act would ensure eligibility, at the expense of the state, for free studies up to completion of 12 years of education, a matriculation certificate, higher education, and professional postgraduate studies.

All of this could be financed by better use of the education budget and monitoring the performances of schools and teachers.

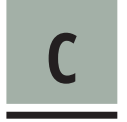

\section{Health}

The Israeli healthcare system has been marked by comparatively poor investment, combined with centralized management and distorted incentives, partly associated with a problematic public-private mix, which contribute both to inefficiencies and to disparities in health (see above) across communities and populations (Chernichovsky, 2020).

31 | Sustainable Well-Being in Israel 
Current Israeli health metrics are a result of past investments and may be unsustainable if current policy prevails (Bowers \& Chernichovsky, 2017). New investments (Chernichovsky, 2020) are needed in order to come to terms with Israel's fast-aging population and the inferior health of women compared to those in other developed countries, on the one hand, and of the Arab population, on the other. Such investments could boost Israel's relative standing in life expectancy.

The focus of policy and investment needs to change from prevention of death to improving the quality of life, including the prevention of disability and the management and cure of pain. This is apparent from the working of the "HealthBasket Committee," which decides what new technologies and medicines Israelis should be entitled to receive via their Health Funds (Chernichovsky \& Bowers, 2014). More attention should be given to metrics like healthy life years, DALYs, and QALYs, which are not usually taken into account in prioritizing interventions in Israel.

Any policy must be based on sound data involving relevant metrics that can be used for policy and program design. This is no mean task, as the statistics relating to the health of the population and the performance of the health services are often inadequate. In the Appendix, I suggest general categories of requisite data that need further development. 


\section{References}

Alexander, K. (1996). The value of an education. Boston: Simon \& Schuster.

Arrow, K., Dasgupta, P., \& Mumford, M. (2014). Health capital. In UNU-IHDP \& UNEP (ed.). Inclusive wealth report 2014: Measuring progress toward sustainability (pp. 123-134). Cambridge: Cambridge University Press.

Barro, R. (1996). Health and economic growth. Mimeograph, Harvard University.

Barro, R. (1997). Determinants of economic growth: A cross-country empirical study. Lionel Robbins Lectures. Cambridge, MA: MIT Press.

Barro, R. \& Sala-i-Martin, X. (1995). Economic growth. New York: McGraw-Hill.

Becker, G. S. (1994) [1964]. Human capital: A theoretical and empirical analysis with special reference to education (3rd ed.). Chicago: University of Chicago Press.

Ben-David, D. (2017-2018). The Shoresh handbook: Education and its impact in Israel, 20172018. Tel Aviv: Shoresh Institution for Socioeconomic Research.

Ben-David, D. (2019). Doing (learning) the math in Israel: Conflicting demographic trends and the core curriculum. Tel Aviv: Shoresh Institution for Socioeconomic Research.

Bhargava, A., Jamison, D., Lau, L., \& Murray, C. (2001). Modeling the effects of health on economic growth. Journal of Health Economics, 718, 1-18.

Blass, N. (2020). Recommendations for an equitable and performing education system. In $Y$. Harpaz \& E. Horowitz (Eds.), Education at a crossroads. Israel: The Branco Weiss Institute and Kineret Zmora Dvir Publishers (Hebrew).

Bloom, D. E., \& Canning, D. (2000). The health and wealth of nations. Science, 287, 12071209.

Bloom, D., \& Canning, D. (2003). Health as human capital and its impact on economic performance. Geneva Papers on Risk \& Insurance: Issues \& Practice, 28(2), 304-315.

Bloom, D., Canning D., \& Sevilla, J. (2001). The effect of health on economic growth: Theory and evidence. NBER Working Papers, No. 8587. Cambridge, MA: National Bureau of Economic Research (NBER).

Bloom, D., Canning, D., \& Sevilla, J. (2003). The demographic dividend: A new perspective on the economic consequences of population change. Santa Monica, CA: RAND Corporation.

Boldizzoni, F. (2008). Means and ends: The idea of capital in the west, 1500-1970. New York: Palgrave Macmillan

Bowers, L. \& Chernichovsky, D. (2017). Reconsidering Israel's health priorities. Policy Paper no. 2017.2. Jerusalem: Taub Center for Social Policy Research in Israel.

Carrillo-Tudela, C. (2012). Job search, human capital and wage inequality. CESifo Working Paper Series, No. 3979. Ludwig Maximilian University Munich: Center for Economic Studies.

Cheatham, A. (2020). What is Canada's immigration policy? NY: Council on Foreign Relations.

33 | Sustainable Well-Being in Israel 
Chernichovsky, D. (2020). The health system: An overview. In A. Weiss (Ed.), The state of the nation report, 2019. Jerusalem: Taub Center for Social Policy Research in Israel.

Chernichovsky, D., \& Bowers, L. (2014). Health status and healthcare system budgeting in Israel in the context of Disability-Adjusted Life Years (DALYS). Policy Paper No. 2014.18. Jerusalem: Taub Center for Social Policy Research in Israel.

Chernichovsky, D., \& Sharony, C. (2015). The relationship between social capital and health in the Haredi sector. In D. Chernichovsky \& A. Weiss (Eds.), The state of the nation report, 2015. Jerusalem: Taub Center for Social Policy Research in Israel.

Chernichovsky, D., Sharony, C., Bowers, L., \& Bisharat, B. (2020). The health of a population in transition: The Israeli-Arab. In I. Laher (Ed.), Handbook of healthcare in the Arab world. Cham: Springer.

Cooray, A. (2013). Does health capital have differential effects on economic growth? Applied Economics Letters, 20(3), 244-249.

Demographic characteristics of internal migration 2003-2005 (n.d.). Israel: Central Bureau of Statistics. (Hebrew). https://www.cbs.gov.il/he/publications/doclib/2008/in_ migrationo5/pdf/intro_h.pdf

Denison, E. F. (1962). The sources of economic growth in the United States and the alternatives before us. NY: Committee for Economic Development.

Ehrlich, T. (2000). Civic responsibility and higher education. Westport, CT: American Council on Education and Oryx Press.

Frank, R. H., \& Bernanke, B. S. (2007). Principles of microeconomics (3rd ed.). New York: McGrawHill/Irwin.

Fuchs, V. R. (1972). (ed.) Essays in the economics of health and medical care. New York: National Bureau of Economic Research.

Garavan, T. N., et al. (2001). Human capital accumulation: The role of human resource development. Journal of European Industrial Training, 25(2), 48-68.

Georgescu-Roegen, N. (1971). The entropy law and the economic process. Cambridge, MA: Harvard University Press.

Gould, E. D., \& Moav, O. (2007). Israel's brain drain. Israel Economic Review, 5(1), 1-22.

Greider, P., Denise-Neinhaus, S., \& Statham, A. (1992). Education and training as facilitating reemployment after a plant shutdown. Sociological Practice Review, 3, 220-227.

Grossman, M. (1972). On the concept of health capital and the demand for health. Journal of Political Economy, 80(2), 223-255.

Grubb, W. N., \& Lazerson, M. (2004). The education gospel: The economic power of schooling. Cambridge, MA: Harvard University Press.

Harris, J., \& Todaro, M. (1970). Migration, unemployment and development: A two-sector analysis. American Economic Review, 60(1), 126-142.

Hamoudi, A. A., \& Sachs, J. D. (1999). Economic consequences of health status: A review of the evidence. Harvard Center for International Development, Working Paper No. 30.

Jones-Lee, M. (1976). The value of life: An economic analysis. Chicago: University of Chicago Press.

Klarman, H. E. (1965). The economics of health. New York: Columbia University Press.

Kwon, D. B. (2009). Human capital and its measurement. The 3rd OECD World Forum on "Statistics, knowledge and policy": Charting progress, building visions, improving life. Busan, Korea, October 27-30, 2009. http://www.oecd.org/site/progresskorea/44111355. pdf

34 | Sustainable Well-Being in Israel 
Malthus, T. R. (1986) [1798]. An essay on the principle of population. In The Works of Thomas Robert Malthus, Vol. 1 (pp. 1-139). London: Pickering \& Chatto.

Mirowsky, J., \& Ross, C. E. (1998). Education, personal control, lifestyle and health: A human capital hypothesis. Research on Aging, 20(4), 415-449.

Mishra, S., \& Nathan, H. S. K. (2013). Measuring human development index: The old, the new and the elegant (No. 2013-020). Mumbai: Indira Gandhi Institute of Development Research.

Murphy, K. M., \& Topel, R. H. (2006). The economic value of medical research. In K. M. Murphy and R. H. Topel (Eds.) Measuring the gains from medical research: An economic approach. Chicago: University of Chicago Press.

Mushkin, S. J. (1962). Health as an investment. Journal of Political Economy, Supplement, 70, 129-157.

OECD (2019). Education at a glance, 2019: OECD indicators. Paris: OECD Publishing. https://www.oecd-ilibrary.org/education/education-at-a-glance-2019_f8d7880d-en

Preston, S. (1975). The changing relation between mortality and the level of economic development. Population Studies, 29, 231-248.

Pritchett, L., \& Summers, L. (1996). Wealthier is healthier. Journal of Human Resources, $31(4), 844-868$.

Rastogi, P. N. (2002). Knowledge management and intellectual capital as a paradigm of value creation. Human Systems Management, 21(4), 229-240.

Razin, A. (2018). Israel's immigration story: Winners and losers. Israel Economic Review, 15, 73-106. https://www.boi.org.il/en/Research/Periodicals/Documents/volume\%20 $15.1 / \% \mathrm{D} 7 \% \mathrm{~A} 4 \% \mathrm{D} 7 \% \mathrm{~A} 8 \% \mathrm{D} 7 \% \mathrm{~A} 7 \% 203 . \mathrm{pdf}$

Rebhun, U., \& Brown, D. (2015). Patterns and selectivities of urban/rural migration in Israel. Demographic Research, 33, 113-144. https://www.researchgate.net/ publication/281801277_Patterns_and_selectivities_of_urbanrural_migration_in_Israel

Reynolds, A. J., Rolnick, A. J., Englund, M. M., \& Temple, J. A. (2010). Early childhood development and human capital: A human capital integration. In A. J. Reynolds, A. J. Rolnick, M. M. Englund, \& J. A. Temple (Eds.), Cost effective programs in children's first decade: A human capital integration (pp. 1- 26). New York: Cambridge University Press.

Roberts, N. T. (1959). The values and limitations of periodic health examinations. Journal of Chronic Diseases, 9(2), 95-116.

Rodriguez, P. J., \& Loomis, R. S. (2007). A new view of institutions, human capital, and market standardization. Education, Knowledge \& Economy, 1(1), 93-105.

Rolnick, A. J., \& Grunewald, R. (2003). Early childhood development: Economic development with a high public return. The Region, 17(4), 6-12.

Rosen, S. (1988). The value of changes in life expectancy, Journal of Risk and Uncertainty, 1, 285-304.

Schoellman, T. (2016). Early childhood human capital and development. American Economic Journal: Macroeconomics, 8(3), 145-174.

Schultz, T. W. (1961). Investment in human capital. American Economic Review, 51(1), 1-17.

Sen, A. (1997). Human capital and human capability. World Development, 25(12), 1959-1961.

Sen, A. (1999). Development as freedom. New York: Anchor Books.

Sidorkin, M. A. (2007). Human capital and the labor of learning: A case of mistaken identity. Educational Theory, 57(2). 159-170.

Simon, J. L. (1981). The ultimate resource. Princeton: Princeton University Press.

35 | Sustainable Well-Being in Israel 
Tur-Sinai, A., Zontag, N., Blondheim, O., Weinreb, A., \& Chernichovsky, D. (2020). Physicians in Israel: Trends in characteristics and training. Jerusalem: Taub Center for Social Policy Research in Israel. http://taubcenter.org.il/wp-content/files_mf/ physiciansinisraeltrendsincharacteristicsandtraining.pdf

UNFPA (United Nations Population Fund) (2020) Demographic dividend. Retrieved January 25. 2021, from https://arabstates.unfpa.org/en/topics/demographic-dividend6\#: : text=A\%20country $\% 20$ with $\% 20$ both $\% 20$ increasing,to $\% 20$ the $\% 20$ number $\% 200 f \% 20$ dependents

Usher, D. (1973). An imputation to the measure of economic growth for changes in life expectancy. In M. Moss (Ed.), The Measurement of economic and social performance: Studies in income and wealth, Vol. 38 (pp. 193-225). New York: Conference on Research in Income and Wealth, National Bureau of Economic Research, and Columbia University Press.

Vaknin, D., Shavit, Y., \& Sasson, Y. (2020). The inequality generated at early childhood and future scholastic achievements. In A. Weiss (Ed.), The state of the nation report, 2019. Jerusalem: Taub Center for Social Policy Research in Israel.

Vinokur, A., et al. (2000). Two years after a job loss: Long-term impact of the jobs program on reemployment and mental health. Journal of Occupational Health Psychology, 5, 32-47.

Weinreb, A. (2020a). Population projections for Israel, 2017-2040. Jerusalem: Taub Center for Social Policy Research in Israel.

Weinreb, A. (2020b). The projected effects of population and enrollment growth on the number of students in higher education in Israel, 2018-2040. Draft 2. Jerusalem: Taub Center for Social Policy Research in Israel.

Weinreb, A., \& Blass, N. (2018). Trends in religiosity among the Jewish population in Israel. Policy Paper No. 02.2018. Jerusalem: Taub Center for Social Policy Research in Israel.

Weinreb, A., Chernichovsky, D., \& Brill, A. (2018). Israel's exceptional fertility. Jerusalem: Taub Center for Social Policy Research in Israel.

World Bank (1993). World development report 1993: Investing in health. Washington, D.C.: World Bank.

Youndt, M. A., et al. (2004). Intellectual capital profiles: An examination of investments and returns. Journal of Management Studies, 41(2). 335-361.

Additional sources:

Becker, G. S. (2007). Health as human capital: Synthesis and extensions. Oxford Economic Papers, 59(3), 379-410.

Becker, G. S., \& Chiswick, B. R. (1966). Education and the distribution of earnings. American Economic Review, 56(1/2), 358-369.

Case, A., \& Deaton, A. (2005). Broken down by work and sex: How our health declines. In D. Wise (Ed.), Analyses in the economics of aging (pp. 185-212). Chicago: University of Chicago Press.

Dardanoni, V., \& Wagstaff, A. (1987). Uncertainty, inequalities in health and the demand for health. Journal of Health Economics, 6, 283-390.

Frish, R. (2009). The economic returns to schooling in Israel. Israel Economic Review, 7(1), 113-141.

Galama, T. J. (2011). A contribution to health capital theory. RAND Working Paper Series No. WR-831. Santa Monica, CA: RAND Corporation.

Griliches, Z. (1977). Estimating the returns to schooling: Some econometric problems. Econometrica, 45(1), 1-22.

36 | Sustainable Well-Being in Israel 
Lepak, D., \& Snell, S. (1999). The human resource architecture: Toward a theory of human capital allocation and development. Academy of Management Review, 24, 31-48.

Mincer, J. (1974). Schooling, experience, and earnings. New York: Columbia University Press, for the National Bureau of Economic Research.

Psacharopoulos, G. (1994). Returns to investment in education: A global update. World Development, 22(9), 1325-1343.

Romer, P. M. (1990). Endogenous technological change. Journal of Political Economy, 98(5, Part 2), S71-S102.

Selden, T. M. (1993). Uncertainty and health care spending by the poor: The health capital model revisited. Journal of Health Economics, 12(1), 109-115.

Wagstaff, A. (1986). The demand for health: Some new empirical evidence. Journal of Health Economics, 5, 195-233.

Weisberg, J. (1995). Returns to education in Israel: 1974 and 1983. Economics of Education Review, 14(2), 145-154.

Zweifel, P., \& Breyer, F. (1997). Health economics. New York: Oxford University Press.

בנק ישראל (2019). דוח מיוחד של חטיבת המחקר: העלאת רמת החיים בישראל באמצעות הגדלת פריון העבודה. ירושלים: בנק ישראל.

בנק ישראל (2019). דו"ח בנק ישראל 2018, פרק ה': הפריון ומיומנויות היסוד של העובדים בישראל: השוואה בין-לאומית. ירושלים: בנק ישראל.

ברנד, גלעד (2017). מדוע הפריון במדינת הסטארט-אפ נותר נמוך? ירושלים: מרכז טאוב לחקר המדיניות החברתית בישראל. 


\section{Appendixes}

\section{Appendix 1. Human Capital Metrics by Categories}

\section{Population}

Fertility levels by relevant population groups

Age and gender distributions

Internal migration by source and destination, population characteristics, and causes

International migration by age, gender, and migrant characteristics (including country of origin)

Emigration by age, gender, and migrant characteristics (including country of destination)

Population projections overall and by specific groups, with emphasis on projected health, education, and life-style needs, and dependency ratios

\section{Health}

\section{Status/outcome}

Life expectancy at birth and for other age groups

Infant mortality

Healthy life years

Disability-adjusted life years (DALYs)

Quality-adjusted life years (QALYs)

Age and group-specific mortality, by causes of death

Health risk factors (e.g., obesity and exposure to health hazards)

Nutritional status, especially of children, by population groups

Physical activity

Medical personnel, by personal characteristics, types, and specialties 


\section{Inputs/processes}

Medical infrastructure and equipment, by type (e.g., clinics, hospitals, specialty centers, beds, MRI units, etc.)

Adequacy of personnel and infrastructure to need, by location and population group

Access to care and waiting times

"Technological literacy" of medical personnel

Overall and public allocation to medical care by categories of care (e.g., prevention)

Levels and uses of private finance, including insurance

Allocation of MDs' time between private and public practices

Retirement of medical personnel, by reason given

Projections of health needs vs medical resources

Adequacy of medical personnel and infrastructure, by needs

Speed of adoption and deployment of new technologies

Use of new technologies

Regulation and decentralization indices

\section{Education and Training}

\section{Status/outcome}

Populations, by levels of education

Enrollment, by types of training

Characteristics of enrollees, by types of training

Test scores in various subject areas and for different age groups

High school completion rates

University and college completion rates

Educational completion rates, by socio-economic characteristics

Skill shortages in specific areas

In-and out-migration of persons with specific skill sets.

\section{Inputs/processes}

Public and private spending on education, by type of spending and character of spenders

Educational infrastructure

Student-teacher ratios, by population groups

Quality and performance of teachers 
Teachers' allocation of time

Teachers' retirement practices

Availability of teaching materials

Incidence and length of workplace training

Extent of government training and retraining programs

Extent of post-secondary educational opportunities

Enrolment rates in specific programs, such as retraining

Lifelong learning culture and practices, formal and informal

Projections of educational needs vs resources

Adequacy of educational personnel and infrastructure, by needs

Speed of adoption and deployment of new technologies

Use of new technologies

Social and emotional learning

Regulation and decentralization indices 


\section{Sustainable Well-Being in Israel}

Report of the Expert Committee of The Israel Academy of Sciences and Humanities

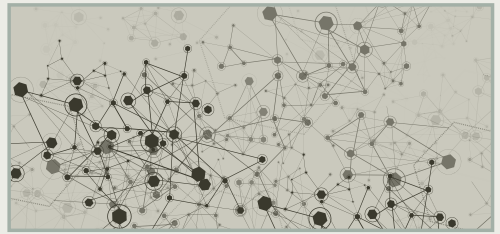

\section{The Capital Approach}

Selected Topics in the Capital Approach to Sustainability

(Hebrew)

Asaf Tzachor

https://doi.org/10.52873/Policy.2021.Wellbeing.01

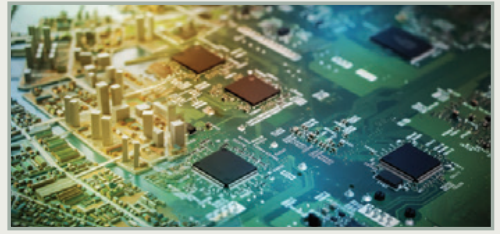

\section{Economic Capital}

Economic Capital, Its Components, and the Situation in Israel (Hebrew)

Michael Sarel

https://doi.org/10.52873/Policy.2021.Wellbeing.02

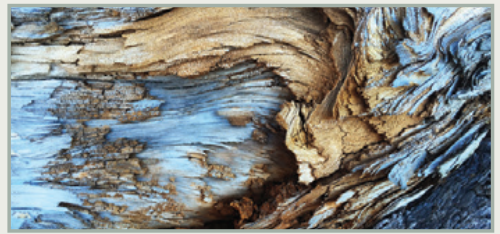

\section{Natural Capital}

Natural Capital and Critical Natural Capital in Israel

(Hebrew)

Asaf Tzachor

https://doi.org/10.52873/Policy.2021.Wellbeing.03

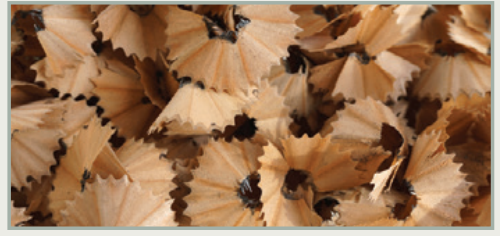

\section{Human Capital}

Israel - The Human Capital Perspective

Dov Chernichovsky

https://doi.org/10.52873/Policy.2021.Wellbeing.04-en

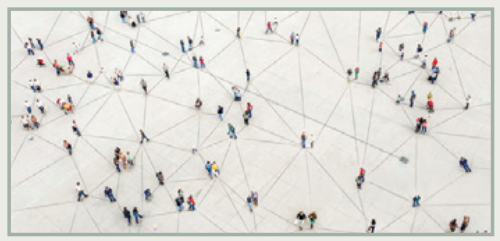

\section{Social Capital}

Building Social Capital for Sustainable Well-Being in Israel: A Scientific Review Yinnon Geva, Itay Greenspan and Michal Almog-Bar https://doi.org/10.52873/Policy.2021.Wellbeing.05-en

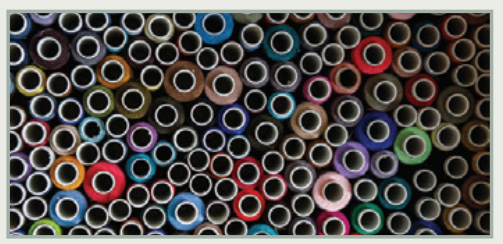

\section{Cultural Capital}

Culture and the Future Sustainability

of Well-being in Israeli Society

Tally Katz-Gerro

https://doi.org/10.52873/Policy.2021.Wellbeing.06-en

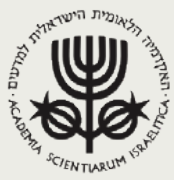

